\title{
The Affordability of MyPlate: An Analysis of SNAP Benefits and the Actual Cost of Eating According to the Dietary Guidelines
}

\author{
Kranti Mulik, $\mathrm{PhD}^{1}$; Lindsey Haynes-Maslow, $\mathrm{PhD}, \mathrm{MHA}^{2}$
}

\begin{abstract}
Objective: To estimate the funds required to support a MyPlate diet and to estimate the additional costs needed for Supplemental Nutrition Assistance Program recipients to adhere to the MyPlate diet.

Design: Using the US Department of Agriculture's (USDA's) MyPlate dietary guidelines that specify recommendations for individuals based on age and gender and retail price data from the USDA, the cost of following USDA's MyPlate guidelines for consuming 3 meals daily was estimated for the following individuals: children, adolescents, female adults, male adults, female seniors, male seniors, and a 4-person family.
\end{abstract}

Main Outcome Measures: Cost of consuming a MyPlate diet, including canned, frozen, and fresh produce as part of the diet.

Analysis: Descriptive analysis of the cost of consuming a MyPlate diet.

Results: Consuming a MyPlate diet consisting of only fresh fruits and vegetables is the most expensive diet. The monthly additional costs on an individual basis is the largest for boys aged 12-17 years $(\$ 75 / \mathrm{mo})$ because they have the largest quantity of food consumed compared with all other gender and age groups. The monthly cost for a family of 4 ranged from $\$ 1,109$ to $\$ 1,249 / \mathrm{mo}$.

Conclusions and Implications: The monetary amount of Supplemental Nutrition Assistance Program benefits may be insufficient to support a healthy diet recommended by federal nutrition guidelines.

Key Words: nutrition, food assistance program, federal dietary guidelines, low-income, SNAP, MyPlate, food cost (J Nutr Educ Behav. 2017;49:623-631.)

Accepted June 11, 2017.

\section{INTRODUCTION}

Over the past 30 years, obesity rates among adults in the US have more than doubled and approximately two-thirds of adults are currently overweight or obese., ${ }^{1,2}$ Consuming healthy foods, including fruits and vegetables, whole grains, and lean proteins, can prevent weight gain and reduce the risk of diet-related chronic diseases, including heart disease, diabetes, and some cancers. ${ }^{3}$ Low-income individuals are more vulnerable to diet-related chronic disease. ${ }^{4}$ Having limited resources is 1 reason why low-income individuals are less likely than higher-income individuals to adhere to the federal Dietary Guidelines for Americans. ${ }^{5}$ This includes not being able to afford purchasing healthier foods, lack of geographic access to healthy foods, and not having time to prepare and cook healthy foods. ${ }^{5,6}$

The US Federal Government created the Supplemental Nutrition Assistance Program (SNAP) in 1939 to

\footnotetext{
${ }^{1}$ Food and Environment Program, Union of Concerned Scientists, Washington, DC

${ }^{2}$ Department of Agricultural and Human Sciences, North Carolina State University, Raleigh, NC

Conflict of Interest Disclosure: The authors' conflict of interest disclosures can be found online with this article on www.jneb.org.

Address for correspondence: Lindsey Haynes-Maslow, PhD, MHA, Department of Agricultural and Human Sciences, North Carolina State University, 512 Brickhaven Dr, Raleigh, NC 27695; Phone: (919) 515-9125; Fax: (919) 515-4241; E-mail: lhmaslow@ncsu.edu (C)2017 Society for Nutrition Education and Behavior. Published by Elsevier, Inc. All rights reserved.

alleviate food insecurity. ${ }^{7}$ Since its creation, SNAP has shifted its focus to include improving dietary intake. ${ }^{7}$ It is the largest federal food assistance program that offers benefits usable as cash for the purchase of food by lower-income individuals in the US, serving $27 \%$ of all children and approximately 21 million households. ${ }^{8}$ Generally, households whose incomes are $<130 \%$ of the poverty level and pass an asset test are eligible for SNAP. Families can spend their benefits on foods to be eaten at home. The average monthly benefit per person is $\$ 125$ and \$254 per household, and nearly all benefits are spent by the end of the month. ${ }^{8}$ In 2015, SNAP provided more than $\$ 75$ billion in benefits to approximately 47 million people. ${ }^{9}$ Most of these people lived in households with children.

Overall, research showed that SNAP is effective at reducing food insecurity. ${ }^{10-12}$ One study indicated that SNAP reduced food insecurity by approximately $30 \% .^{10}$ In addition to 
Table 1. Average Price of Protein, Fruits, Vegetables, Dairy, and Grains, in 2015 Dollars

\begin{tabular}{|c|c|c|c|c|}
\hline Food Category & Type & Processing & \$/Cup & $\$ / O z$ \\
\hline Protein & Lean beef, ${ }^{a}$ poultry, ${ }^{b}$ eggs ${ }^{c}$ & - & 0.21 & - \\
\hline Protein (vegetarian) & $\begin{array}{l}\text { Beans } \\
\text { Beans }\end{array}$ & $\begin{array}{l}\text { Frozen, }^{d} \text { canned, }^{e} \text { dried }^{f} \\
\text { Frozen }^{d}\end{array}$ & $\begin{array}{l}0.49 \\
0.64\end{array}$ & $\begin{array}{l}0.08 \\
0.10\end{array}$ \\
\hline Protein & Beans & Canned, dried ${ }^{e, f}$ & 0.42 & 0.07 \\
\hline Fruits & $\begin{array}{l}\text { Fruit } \\
\text { Fruit } \\
\text { Fruit } \\
\text { Fruit }\end{array}$ & $\begin{array}{l}\text { Fresh }^{g} \\
\text { Frozen }^{h} \\
\text { Canned } \\
\text { Dried }\end{array}$ & $\begin{array}{l}0.82 \\
0.72 \\
0.89 \\
0.84\end{array}$ & $\begin{array}{l}- \\
- \\
- \\
-\end{array}$ \\
\hline Vegetables & $\begin{array}{l}\text { Vegetables } \\
\text { Vegetables } \\
\text { Vegetables } \\
\text { Vegetables and beans } \\
\text { Vegetables and beans }\end{array}$ & $\begin{array}{l}\text { Fresh }^{j} \\
\text { Frozen }^{k} \\
\text { Canned' } \\
\text { Frozen } \\
\text { Canned, dried }\end{array}$ & $\begin{array}{l}0.88 \\
0.92 \\
0.78 \\
0.80 \\
0.61\end{array}$ & $\begin{array}{l}- \\
- \\
- \\
- \\
-\end{array}$ \\
\hline Dairy & Low-fat dairy ${ }^{m}$ & - & 0.27 & - \\
\hline Grains & $\begin{array}{l}\text { Whole grains }{ }^{n} \\
\text { Non-whole grains }^{\circ}\end{array}$ & $\begin{array}{l}- \\
-\end{array}$ & $\begin{array}{l}- \\
-\end{array}$ & $\begin{array}{l}0.21 \\
0.12\end{array}$ \\
\hline
\end{tabular}

${ }^{a}$ Beef price was for lean and extra-lean ground beef $(\$ / \mathrm{lb})$; ${ }^{\mathrm{b}}$ The retail price for poultry was the average of fresh whole chicken; chicken breast, bone-in; chicken legs, bone-in; boneless breast chicken; and whole frozen turkey; ${ }^{\circ}$ Egg prices were for grade A

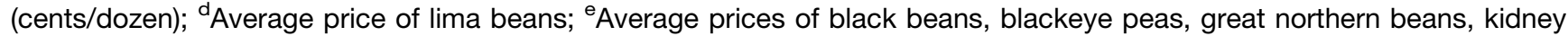
beans, lima beans, navy beans, and pinto beans; ${ }^{f}$ Average prices of black beans, blackeye peas, great northern beans, kidney beans, lentils, lima beans, navy beans, and pinto beans; ${ }^{9}$ Average prices of apples, apricots, bananas, blackberries, cantaloupes, grapefruit, grapes, honeydew, kiwis, mangoes, nectarines, oranges, papayas, peaches, pears, pineapples, plums, pomegranates, raspberries, strawberries, tangerines, and watermelons; ${ }^{\mathrm{h}}$ Average prices of apples, mixed berries, blackberries, grapefruit, grapes, oranges, peaches, pineapples, raspberries, and strawberries; 'Average prices of apples, peaches, pears, and pineapples; 'Average prices of acorn squash, artichokes, asparagus, avocados, broccoli, brussels sprouts, butternut squash, cabbage, carrots, cauliflower, sweet corn, cucumbers, green peppers, kale, iceberg lettuce, romaine lettuce, mushrooms, mustard greens, okra, onions, radishes, red peppers, spinach, summer squash, sweet potatoes, tomatoes, and turnip greens; ${ }^{k}$ Average prices of artichokes, asparagus, broccoli, brussels sprouts, sweet corn, green peas, kale, mixed vegetables, mustard greens, okra, spinach, and turnip greens; 'Average prices of artichokes, asparagus, beets, cabbage, sweet corn, green peas, kale, mixed vegetables, mustard greens, olives, pumpkin, spinach, tomatoes, and turnip greens; ${ }^{\mathrm{m}}$ Dairy prices were the average of low-fat milk, low-fat cheese, low-fat yogurt, and other dairy; "Whole grains include the average of whole-grain bread, rolls, rice, pasta, cereal, whole-grain flour and mixes, and whole-grain frozen/ready to cook grains; ${ }^{\circ}$ Non-whole grains are the average of other bread, rolls, rice, pasta, cereal, other flour and mixes, and other frozen/ready to cook grains.

Notes: Data are from the US Department of Agriculture. ${ }^{22}$ All prices were adjusted to 2015 dollars.

reducing food insecurity, there was also research to support that SNAP improves child and adult health outcomes, including physical and mental health. ${ }^{13}$ Despite these positive findings, many families receiving SNAP report significant financial barriers to purchasing healthy food with their benefits. ${ }^{14,15}$ This may partially explain why studies on SNAP recipients' diets showed that compared with nonrecipients, SNAP recipients have lower diet quality. ${ }^{16,17}$ Although SNAP is meant to be a supplementary aid program and is not intended to finance the entire cost of eating a healthy diet, recent federal budget proposals suggested decreasing the amount of SNAP benefits available for food. ${ }^{18}$ Reducing the amount of SNAP benefits available for eligible individuals may decrease the program's ability to support healthier diets among food-insecure individuals and families.

In 2011, the USDA calculated the cost of various food plans (low-cost, moderate cost, and liberal) based on federal dietary guidelines. ${ }^{19}$ The organization determined that adhering to a nutritious low-cost diet would cost $\$ 147 /$ wk for a family of 4 (4 adults aged 20-50 years and 2 children aged 6-8 and 9-11 years). The report concluded that it would be possible for people to eat healthier, including more vegetables and fruits, and spend less on food. However, the USDA's analysis was not based on the current federal dietary guidelines, and calculations were based on the 2005 Food Pyramid dietary guidelines instead of the more recent MyPlate, which replaced the Food Pyramid in 2010. ${ }^{20}$ Several notable changes included renaming the meat and beans and milk groups to the protein and dairy groups to allow for lacto-ovo vegetarian and vegan eating patterns, respectively. $^{21}$ In addition, MyPlate modified the structure and composition of vegetable subgroups to promote diversity of vegetables. ${ }^{21}$ Because of the changes in food groups and subgroups from the Food Pyramid to MyPlate, the USDA's 2011 analysis using the Food Pyramid to calculate the low-cost diet may not be as accurate. 
Table 2. MyPlate Daily Nutrition Guidelines, by Gender and Age Group

\begin{tabular}{|c|c|c|c|c|c|c|c|}
\hline Group & Age, y & Fruit, cups & Vegetables, cups & Grains, oz & Whole Grains, oz $^{\mathrm{a}}$ & Protein, oz & Dairy, cups \\
\hline Children & $\begin{array}{l}2-3 \\
4-8\end{array}$ & $\begin{array}{l}1 \\
1.25\end{array}$ & $\begin{array}{l}1 \\
1.5\end{array}$ & $\begin{array}{l}3 \\
5\end{array}$ & $\begin{array}{l}1.5 \\
2.5\end{array}$ & $\begin{array}{l}2 \\
4\end{array}$ & $\begin{array}{l}2 \\
2.5\end{array}$ \\
\hline Girls & $\begin{array}{r}9-13 \\
14-18\end{array}$ & $\begin{array}{l}1.5 \\
1.5\end{array}$ & $\begin{array}{l}2 \\
2.5\end{array}$ & $\begin{array}{l}5 \\
6\end{array}$ & $\begin{array}{l}3 \\
3\end{array}$ & $\begin{array}{l}5 \\
5\end{array}$ & $\begin{array}{l}3 \\
3\end{array}$ \\
\hline Boys & $\begin{array}{r}9-13 \\
14-18\end{array}$ & $\begin{array}{l}1.5 \\
2\end{array}$ & $\begin{array}{l}2.5 \\
3\end{array}$ & $\begin{array}{l}6 \\
8\end{array}$ & $\begin{array}{l}3 \\
4\end{array}$ & $\begin{array}{l}5 \\
6.5\end{array}$ & $\begin{array}{l}3 \\
3\end{array}$ \\
\hline Women & $\begin{array}{l}19-30 \\
31-50 \\
\geq 51\end{array}$ & $\begin{array}{l}2 \\
1.5 \\
1.5\end{array}$ & $\begin{array}{l}2.5 \\
2.5 \\
2\end{array}$ & $\begin{array}{l}6 \\
6 \\
5\end{array}$ & $\begin{array}{l}3 \\
3 \\
3\end{array}$ & $\begin{array}{l}5.5 \\
5 \\
5\end{array}$ & $\begin{array}{l}3 \\
3 \\
3\end{array}$ \\
\hline Men & $\begin{array}{l}19-30 \\
31-50 \\
\geq 51\end{array}$ & $\begin{array}{l}2 \\
2 \\
2\end{array}$ & $\begin{array}{l}3 \\
3 \\
2.5\end{array}$ & $\begin{array}{l}8 \\
7 \\
6\end{array}$ & $\begin{array}{l}4 \\
3 \\
3\end{array}$ & $\begin{array}{l}6.5 \\
6 \\
5.5\end{array}$ & $\begin{array}{l}3 \\
3 \\
3\end{array}$ \\
\hline
\end{tabular}

${ }^{a}$ MyPlate recommends $50 \%$ of grains to be whole grain.

Note: Data are from the US Department of Agriculture. ${ }^{28}$

Because research is often used to inform policy, an analysis using the most current data is needed to inform policy makers regarding the true costs of healthy eating, so that they have up-to-date research when making policy decisions.

More recently, the USDA estimated the cost of satisfying fruit and vegetable requirements under MyPlate guidelines based on 2013 retail scanner data. ${ }^{22}$ Researchers found that consuming MyPlate levels of fruits and vegetables (fresh, canned, frozen, dried, and $100 \%$ juice) would cost between $\$ 2.10$ and $\$ 2.60$ per day, or 47-57 cents/cup-equivalent. For those following a low-cost diet, the USDA found that a family of 4 would need to spend, on average, $\leq 50$ cents/cupequivalent.
To date, no studies have calculated the cost of following MyPlate's dietary recommendations for all food groups (fruits, vegetables, grains, dairy, and protein). To address this knowledge gap, the purposes of this article were to (1) estimate the total costs required to support a MyPlate diet, and (2) estimate the additional costs needed for SNAP recipients to adhere to a nutritionally sound diet.

\section{METHODS}

\section{Data Sources}

This study used the most current publicly available data from the USDA's retail prices and SNAP eligibility data, which were necessary to conduct a thorough analysis. Monthly retail price data for beef, poultry cuts, and
Table 3. Corresponding Age Groups from Supplemental Nutrition Assistance Program Household Data and MyPlate Dietary Guidelines

\begin{tabular}{ll}
$\begin{array}{l}\text { Age Group, y (Supplemental Nutrition } \\
\text { Assistance Program Recipient Data) }\end{array}$ & $\begin{array}{c}\text { Corresponding MyPlate } \\
\text { Age Group, y }\end{array}$ \\
\hline Children 2-4 & Children 2-3 \\
\hline Children 5-7 & Children 4-8 \\
\hline Girls $8-11$ & Girls 9-13 \\
Girls 12-15 & Girls 14-18 \\
\hline Girls 16-17 & Girls 14-18 \\
Women 18-50 & Women 19-30 and 31-50 \\
\hline Women $\geq 51$ & Women $\geq 51$ \\
\hline Men 18-50 & Men 19-30 and 31-50 \\
\hline Men $\geq 51$ & Men $\geq 51$ \\
\hline
\end{tabular}

Note: Data are from the US Department of Agriculture. ${ }^{28,29}$ eggs from the USDA's Economic Research Service were averaged over the 12 months in 2015 (Table 1). ${ }^{23}$ The average meat price was calculated using the average price of lean beef, poultry, turkey, and eggs to date. ${ }^{23}$ All prices were in dollars per pound and converted to dollars per ounce. The prices for whole grains, other grains, and dairy were obtained from the USDA's 2010 quarterly data for grains and dairy. ${ }^{24}$ The data spanned 99 market groups, 4 regions, and 9 divisions. The prices were adjusted for inflation using the 2015 gross domestic product deflator and converted from dollars per $100 \mathrm{~g}$ to dollars per ounce. Fruits and vegetable prices were from the USDA's Fruit and Vegetable Prices 2013 dataset. Prices were recorded in dollars per cup and adjusted to 2015 dollars using the gross domestic product deflator. ${ }^{25}$ The authors averaged prices for (1) all fresh, frozen, and canned fruit; (2) all fresh, frozen, and canned vegetables; and (3) all frozen, canned, and dried beans. Juice products were excluded from price estimates.

To estimate the funds needed to adhere to a MyPlate diet, SNAP eligibility data by income and household size were used from the USDA's Food, Nutrition, and Consumer Services. $^{26}$ Review by an institutional review board was not required for this study because human subjects were not involved, as per US Department of Health and Human Services guidelines. $^{27}$ 
Table 4. Average Supplemental Nutrition Assistance Program Monthly Benefit for Individuals in 2015

\begin{tabular}{|cc}
$\begin{array}{l}\text { Age-Gender } \\
\text { Groups }\end{array}$ & $\begin{array}{c}\text { Estimated Average Supplemental Nutrition Assistance } \\
\text { Program Monthly Benefit (\$) for Individuals in } 2015\end{array}$ \\
Children & 143.00 \\
$2-4$ y & 143.00 \\
$5-7$ y & \\
Girls & 143.00 \\
$8-11$ y & 143.00 \\
$12-15$ y & 143.00 \\
$16-17$ y & \\
Boys & 143.00 \\
$8-11$ y & 143.00 \\
$12-15$ y & 143.00 \\
$16-17$ y & \\
Women & 127.00 \\
$18-50$ y & 127.00 \\
$\geq 51$ y & \\
\hline Men & 126.00 \\
$18-50$ y & 126.00 \\
\hline Family of 4 & 465.00 \\
\hline
\end{tabular}

Note: Data are from the US Department of Agriculture. ${ }^{29}$

\section{Data Analysis}

Using the USDA's Economic Research Service Food Availability Data, the following MyPlate food groups were created: fruits, vegetables, protein, grains, and dairy. ${ }^{28}$ Using federal dietary guidelines for individuals based on age and gender and retail price data from the USDA, the cost of following USDA's MyPlate guidelines was estimated for consuming 3 daily meals for the following individuals: children (aged 2-4 years), children (aged 5-7 years), girls (aged 811 years), girls (aged 12-15 years), girls (aged 16-17 years), boys (aged 811 years), boys (aged 12-15 years), boys (aged 16-17 years), female adults (aged 18-50 years), male adults (ages

Table 5. Scenarios Used to Calculate Cost of MyPlate Dietary Guidelines Based on Type of Fruit and Vegetables Consumed and Vegetarian Diet ${ }^{20}$

\section{Scenario Description}

\section{Fruits and Vegetables Consumed (\%)}

\begin{tabular}{lrrrcc}
\multicolumn{2}{l}{ Scenario Fresh Frozen Canned } & Vegetable & Diet \\
\hline 1 & 100 & 0 & 0 & No & No \\
2 & 50 & 50 & 0 & No & No \\
\hline $2 a$ & 50 & 50 & 0 & Yes & No \\
\hline 3 & 33 & 33 & 33 & No & No \\
$3 a$ & 33 & 33 & 33 & Yes & No \\
4 & 100 & 0 & 0 & No & Yes \\
\hline 5 & 50 & 50 & 0 & No & Yes \\
\hline 6 & 33 & 33 & 33 & No & Yes \\
\hline
\end{tabular}

18-50 years), female seniors (aged $\geq 51$ years), and male seniors (aged $\geq 51$ years) (Table 2). Because the federal dietary guidelines' age categories are different from the SNAP recipient age categories, ${ }^{29}$ USDA MyPlate age categories were adjusted to correspond to SNAP recipient age categories. Table 3 shows how corresponding age groups were created.

In addition, monthly food costs for a family of 4 were estimated using the following family composition: a family of 4 consisting of 1 male and female (aged 18-30 years) and 2 children (aged 2-4 years and 5-7 years); and another family of 4 consisting of 1 male and female (aged 31-50) and 2 children (aged 8-11 years and 12-17 years). This composition was chosen to allow for a comparison with the USDA's Thrifty Food Plan, which used a similar composition for a family of $4 .^{19}$ In estimating the monthly food costs for adults and a family of 4 , the cost of labor in food preparation was taken into consideration, Because previous studies showed that in addition to food costs, time to prepare meals is a constraining resource when consuming a healthy diet. ${ }^{30}$ Davis and You ${ }^{30}$ estimated that the actual cost share of food was $60 \%$ and the cost of labor for preparing foods accounted for $40 \%$ of the total cost of food. This estimated cost share of food and labor was used first to estimate the total monthly costs of adhering to a MyPlate diet and then to compare this monthly cost with the average monthly SNAP allowances by age and gender. The difference between the cost of eating 3 meals daily according to MyPlate guidelines and the allowance provided by SNAP for each age and gender category (Table 4) was then estimated. In addition to estimating this cost difference, we also accounted for the benefit reduction rate (BRR), which is the percentage of food costs that individuals pay for on their own. Based on a previous study by Ziliak, $^{31}$ which estimated that with all of the formal deductions the BRR ranged from $15 \%$ to $20 \%$, a BRR of $20 \%$ was used in the current study's analysis. Assuming a BRR of $20 \%$ and using the average gross income for all SNAP households of $\$ 786 / \mathrm{mo}$ based on the USDA's 2015 report on SNAP characteristics, the BRR amount 
Table 6. Daily Cost of Consuming MyPlate Recommendations for Fruits and Vegetables Based on Scenarios 1-3

\begin{tabular}{|c|c|c|c|c|}
\hline Group & $\begin{array}{l}\text { Age, } \\
y\end{array}$ & $\begin{array}{c}100 \% \text { Fresh Fruits and } \\
\text { Vegetables (Scenario 1) (\$) }\end{array}$ & $\begin{array}{l}50 \% \text { Fresh, } 50 \% \text { Frozen Fruits } \\
\text { and Vegetables (Scenario 2) (\$) }\end{array}$ & $\begin{array}{l}33 \% \text { Fresh, 33\% Frozen, 33\% Canned } \\
\text { Fruits and Vegetables (Scenario 3) (\$) }\end{array}$ \\
\hline Children & $\begin{array}{l}2-3 \\
4-8\end{array}$ & $\begin{array}{l}1.70 \\
2.35\end{array}$ & $\begin{array}{l}1.67 \\
2.31\end{array}$ & $\begin{array}{r}1.68 \\
2.31\end{array}$ \\
\hline Girls & $\begin{array}{r}9-13 \\
14-18\end{array}$ & $\begin{array}{l}2.99 \\
3.43\end{array}$ & $\begin{array}{l}2.96 \\
3.41\end{array}$ & $\begin{array}{l}2.95 \\
3.38\end{array}$ \\
\hline Boys & $\begin{array}{r}9-13 \\
14-18\end{array}$ & $\begin{array}{l}3.43 \\
4.28\end{array}$ & $\begin{array}{l}3.41 \\
4.24\end{array}$ & $\begin{array}{l}3.38 \\
4.22\end{array}$ \\
\hline Women & $\begin{array}{l}19-30 \\
31-50 \\
\geq 51\end{array}$ & $\begin{array}{l}3.84 \\
3.43 \\
2.99\end{array}$ & $\begin{array}{l}3.79 \\
3.41 \\
2.96\end{array}$ & $\begin{array}{l}3.79 \\
3.38 \\
2.95\end{array}$ \\
\hline Men & $\begin{array}{l}19-30 \\
31-50 \\
\geq 51+\end{array}$ & $\begin{array}{l}4.28 \\
4.28 \\
3.84\end{array}$ & $\begin{array}{l}4.24 \\
4.24 \\
3.79\end{array}$ & $\begin{array}{l}4.22 \\
4.22 \\
3.79\end{array}$ \\
\hline
\end{tabular}

${ }^{\mathrm{a}} P$ for the 2-tailed test tested the difference in the costs of consuming $100 \%$ fresh fruits and vegetables (Scenario 1 ) and of consuming an equal portion of fresh, frozen, and canned fruits and vegetables (Scenario 3) across the different age and gender categories. The difference was not statistically significant at the $5 \%$ level.

Note: Data are from the US Department of Agriculture. ${ }^{23-25}$

was estimated to be: $20 \% \times \$ 786=$ $\$ 157.20$. The additional cost needed for SNAP recipients to adhere to a nutritionally sound diet was estimated as follows: Additional cost $=$ [(MyPlate cost of food including labor) - (SNAP monthly benefits + BRR), where the MyPlate monthly cost of food (including labor) equaled a monthly cost divided by 0.60 ; and the monthly costs and SNAP benefits for a family of 4 were $\$ 658.84$ and $\$ 465$, respectively; and the BRR was $\$ 157.20$. Based on this formula, additional costs for family of 4 with 2 adults (male and female aged 1830 years), 1 child (aged 2-4 years), and 1 child (aged 5-7 years) $=\$ 1098.07-(\$ 465+\$ 157.20)$ $=\$ 475.87$.

\section{Description of Scenarios}

Although MyPlate guidelines encourage the intake of fresh, frozen, and canned fruits and vegetables, the authors estimated the cost of these separately because the flavor quality varies among canned, frozen, and fresh fruits and vegetables. Processing fruits and vegetables varies by commodity, and it is likely that processed forms of produce are accompanied by changes in flavor quality, which can influence intake. ${ }^{32,33}$
Therefore, to estimate the cost of eating 3 daily meals according to MyPlate guidelines for individuals and families, 6 scenarios were created (Table 5). The first scenario estimated the cost of adhering to a nutritionally sound diet, including labor cost, if the recommended daily consumption of fruits and vegetables were all sourced fresh. The second scenario estimated the cost of adhering to a nutritionally sound diet, including labor cost, if half of the daily recommended servings of fruits and vegetables (excluding beans) were sourced fresh and the other half were sourced frozen. Another variation of scenario 2 was created in which the daily recommended servings of fruits and vegetables included beans (scenario 2a). Scenario 3 estimated the cost of adhering to a nutritionally sound diet, including labor cost, if one-third of the daily recommended servings of fruits and vegetables (excluding beans) were sourced fresh, one-third were frozen, and one-third were canned. Similar to scenario 2, 2 variations of scenario 3 were calculated: 1 that did not include beans (scenario 3 ) and 1 that did (scenario 3a). Scenarios 4-6 were similar to scenarios 1-3 but catered to a vegetarian diet in which the main source of protein consisted of beans instead of lean meat and eggs.

\section{RESULTS}

Table 6 shows the variation in daily costs of consuming fresh, frozen, and canned fruits and vegetables, by gender and age. Across all gender and age groups, consuming 100\% fresh fruits and vegetables was the most expensive diet. Consuming an equal portion of fresh, frozen, and canned fruits and vegetables was the least expensive diet; however, these cost differences were not statistically significant. Table 7 shows the monthly cost required to support a MyPlate diet, including labor cost by age, gender, and family size for scenarios 1-6. The monthly cost for a family of 4 with 2 adults (aged 31-50 years) and 2 older children (1 aged 8-11 years and the other 12-17 years) ranged from $\$ 1,249 / \mathrm{mo}$ in scenario 1 (when consuming only fresh fruits and vegetables) to $\$ 1,109$ / mo in scenario 6 for a vegetarian diet consuming one-third fresh, frozen, and canned fruits and vegetables. Similarly, the monthly costs for a family of 4 with 2 adults (aged 19-30 years) and 2 younger children (1 aged 2-4 years and another aged 5-7 years) ranged from a high of $\$ 1,098 / \mathrm{mo}$ in scenario 1 to $\$ 930 / \mathrm{mo}$ in scenario 6 . Table 8 shows the additional monthly costs needed for SNAP recipients if they 
Table 7. Monthly Cost $(\$)$ to Support MyPlate Diet Based on Scenarios

Monthly Cost

\begin{tabular}{|c|c|c|c|c|c|c|c|c|}
\hline \multicolumn{9}{|l|}{ Children } \\
\hline $2-4$ y & 88.34 & 87.50 & 85.54 & 87.69 & 84.58 & 81.17 & 80.33 & 80.52 \\
\hline $5-7 y$ & 131.18 & 130.27 & 127.33 & 130.27 & 125.62 & 116.85 & 115.94 & 115.94 \\
\hline \multicolumn{9}{|l|}{ Girls } \\
\hline $8-11$ y & 160.16 & 159.18 & 155.26 & 158.99 & 152.79 & 142.25 & 141.27 & 141.08 \\
\hline $12-15 y$ & 175.84 & 175.14 & 170.24 & 174.49 & 166.73 & 157.93 & 157.23 & 156.57 \\
\hline $16-17 y$ & 175.84 & 175.14 & 170.24 & 174.49 & 166.73 & 157.93 & 157.23 & 156.57 \\
\hline \multicolumn{9}{|l|}{ Boys } \\
\hline $8-11$ y & 175.84 & 175.14 & 170.24 & 174.49 & 166.73 & 157.93 & 157.23 & 156.57 \\
\hline $12-15 y$ & 217.70 & 216.58 & 210.70 & 216.02 & 206.71 & 194.41 & 193.29 & 192.73 \\
\hline $16-17 y$ & 217.7 & 216.58 & 210.70 & 216.02 & 206.71 & 194.41 & 193.29 & 192.73 \\
\hline \multicolumn{9}{|l|}{ Women } \\
\hline $18-50 y^{a, b}$ & 305.08 & 303.33 & 295.17 & 302.72 & 289.78 & 273.73 & 271.98 & 271.37 \\
\hline$\geq 51 \mathrm{y}^{\mathrm{b}}$ & 266.93 & 265.30 & 258.77 & 264.98 & 254.65 & 237.08 & 235.45 & 235.13 \\
\hline \multicolumn{9}{|l|}{ Men } \\
\hline $18-50 y^{a, b}$ & 355.48 & 353.62 & 343.82 & 352.68 & 337.17 & 318.17 & 316.30 & 315.37 \\
\hline$\geq 51 y^{b}$ & 317.10 & 314.77 & 306.60 & 314.62 & 301.68 & 284.25 & 281.92 & 281.77 \\
\hline \multicolumn{9}{|l|}{ Families $^{b}$} \\
\hline \multicolumn{9}{|l|}{ Family of 4} \\
\hline Male (18-30 y) & $1,098.07$ & $1,038.68$ & $1,012.55$ & $1,037.91$ & 996.53 & 938.31 & 931.19 & 930.42 \\
\hline Female (18-30 y) & & & & & & & & \\
\hline 1 child (2-4 y) & & & & & & & & \\
\hline 1 child (5-7 y) & & & & & & & & \\
\hline Family of $4^{b /}$ & & & & & & & & \\
\hline Male (31-50 y) & $1,249.15$ & $1,243.2$ & $1,208.9$ & $1,239.47$ & $1,185.16$ & $1,119.27$ & $1,113.32$ & $1,109.58$ \\
\hline Female (31-50 y) & & & & & & & & \\
\hline 1 child (8-11 y) & & & & & & & & \\
\hline 1 child (12-17 y) & & & & & & & & \\
\hline$P^{C}$ & .96 & & & & & & & \\
\hline
\end{tabular}

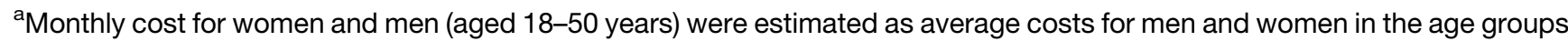
18-30 years and 31-50 years; 'bonthly cost for women and men aged 18-50 years and aged $\geq 51$ years and families of 4 included the cost of labor for food preparation, which accounted for $40 \%$ of total costs based on the estimates of Davis et al. ${ }^{30}$ MyPlate cost of food including labor was estimated as follows: monthly cost/0.6 for each age and gender category across scenarios; ${ }^{c} P$ for the 2 -tailed test tested the difference in monthly costs between the costs of consuming $100 \%$ fresh fruits and vegetables (scenario 1) and the costs of consuming an equal portion of fresh, frozen, and canned fruits and vegetables (scenario 3) across the different age and gender categories. The difference was not statistically significant at the $5 \%$ level.

were to adhere to a nutritionally sound diet. The scenario with the largest additional costs across all individuals by gender, age, and family size was scenario 1. The additional costs needed on an individual basis was the largest for boys aged $12-17$ years $(\$ 75 / \mathrm{mo})$ and men aged $18-50$ years $(\$ 72 / \mathrm{mo})$, because they consumed the largest quantity of food compared with all other gender and age groups.

Among families, a family of 4 with 2 adults (aged 31-50 years) and 2 children (1 child aged 8-11 years and another aged 12-17 years) were the most financially vulnerable to covering the cost of healthy diets.
This type of family would need to incur an additional cost of $\$ 627 / \mathrm{mo}$ to eat a nutritionally sound diet. Similarly, a family of 4 with 2 adults (aged 18-30 years) and 2 younger children (1 aged 2-4 years and another aged 5-7 years) would need to incur an additional cost of $\$ 475 / \mathrm{mo}$. Even in the lowest-cost scenario (scenario 6), the additional cost needed to support a healthy diet was still large: $\$ 487 /$ mo for a family of 4 with 2 adults (aged 31-50 years) and 2 children (1 child aged 8-11 years and another aged 12-17 years); and $\$ 308 / \mathrm{mo}$ for a family of 4 with 2 adults (aged 31-50 years) and 2 older children (1 child aged 8-11 years and another aged 12-17 years). Similarly, in scenario 6 , boys aged 12-17 years and men aged 18-50 years would need additional costs of $\$ 50 / \mathrm{mo}$ and $\$ 32$ / mo, respectively, to eat a healthy diet.

\section{DISCUSSION}

The purpose of this study was to estimate the total costs, including food and labor, required to support a $\mathrm{My}$ Plate diet and the additional costs needed for SNAP recipients to adhere to a nutritionally sound diet. When taking into account the time it takes 
Table 8. Monthly Additional Costs (\$) Needed to Support a MyPlate Diet Based on Scenarios

Monthly Additional Costs Needed ${ }^{a}$

\begin{tabular}{|c|c|c|c|c|c|c|c|c|}
\hline Age-Gender Group & Scenario 1 & Scenario & Scenario $2 \varepsilon$ & Scenario & Scenario 3a & Scenario & Scenario 5 & Scenario 6 \\
\hline $\begin{array}{l}\text { Children } \\
2-4 \text { y } \\
5-7 \text { y }\end{array}$ & $\begin{array}{l}(23.30) \\
(11.82)\end{array}$ & $\begin{array}{l}(55.50) \\
(12.73)\end{array}$ & $\begin{array}{l}(57.46) \\
(15.67)\end{array}$ & $\begin{array}{l}(55.31) \\
(12.73)\end{array}$ & $\begin{array}{l}(58.42) \\
(17.39)\end{array}$ & $\begin{array}{l}\$ 61.83 \\
\$ 26.15\end{array}$ & $\begin{array}{l}\$ 62.67 \\
\$ 27.06\end{array}$ & $\begin{array}{l}\$ 62.48 \\
\$ 27.06\end{array}$ \\
\hline $\begin{array}{l}\text { Girls } \\
\text { 8-11 y } \\
12-15 \text { y } \\
16-17 \text { y }\end{array}$ & $\begin{array}{l}17.16 \\
32.84 \\
32.84\end{array}$ & $\begin{array}{l}16.18 \\
32.14 \\
32.14\end{array}$ & $\begin{array}{l}12.26 \\
27.24 \\
27.24\end{array}$ & $\begin{array}{l}15.99 \\
31.49 \\
31.49\end{array}$ & $\begin{array}{r}9.79 \\
23.73 \\
23.73\end{array}$ & $\begin{array}{l}\$ 0.75 \\
14.93 \\
14.93\end{array}$ & $\begin{array}{l}\$ 1.73 \\
14.23 \\
14.23\end{array}$ & $\begin{array}{l}\$ 1.92 \\
13.57 \\
13.57\end{array}$ \\
\hline $\begin{array}{l}\text { Boys } \\
\begin{array}{l}8-11 \text { y } \\
12-15 y \\
16-17 y\end{array}\end{array}$ & $\begin{array}{l}32.84 \\
74.70 \\
74.70\end{array}$ & $\begin{array}{l}32.14 \\
73.58 \\
73.58\end{array}$ & $\begin{array}{l}27.24 \\
67.70 \\
67.70\end{array}$ & $\begin{array}{l}31.49 \\
73.02 \\
73.02\end{array}$ & $\begin{array}{l}23.73 \\
63.71 \\
63.71\end{array}$ & $\begin{array}{l}14.93 \\
51.41 \\
51.41\end{array}$ & $\begin{array}{l}14.23 \\
50.29 \\
50.29\end{array}$ & $\begin{array}{l}13.57 \\
49.73 \\
49.73\end{array}$ \\
\hline $\begin{array}{l}\text { Women } \\
\quad 18-50 \mathrm{y}^{\mathrm{b}, \mathrm{c}} \\
\geq 51 \mathrm{y}\end{array}$ & $\begin{array}{c}20.88 \\
(17.27)\end{array}$ & $\begin{array}{c}19.13 \\
(18.90)\end{array}$ & $\begin{array}{c}10.97 \\
(25.43)\end{array}$ & $\begin{array}{c}18.52 \\
(19.22)\end{array}$ & $\begin{array}{c}5.58 \\
(29.55)\end{array}$ & $\begin{array}{c}\$ 10.47 \\
(47.12)\end{array}$ & $\begin{array}{c}12.22 \\
(48.75)\end{array}$ & $\begin{array}{c}12.83 \\
(49.07)\end{array}$ \\
\hline $\begin{array}{l}\text { Men } \\
\quad 18-50 y^{b, c} \\
\geq 51 y\end{array}$ & $\begin{array}{l}72.28 \\
33.90\end{array}$ & $\begin{array}{l}70.42 \\
31.57\end{array}$ & $\begin{array}{l}60.62 \\
23.40\end{array}$ & $\begin{array}{l}69.48 \\
31.42\end{array}$ & $\begin{array}{l}53.97 \\
18.48\end{array}$ & $\begin{array}{r}34.97 \\
1.05\end{array}$ & $\begin{array}{c}33.10 \\
(1.28)\end{array}$ & $\begin{array}{c}32.17 \\
(1.43)\end{array}$ \\
\hline $\begin{array}{l}\text { Family of } 4^{\mathrm{c}} \\
\text { Male (18-30 y) } \\
\text { Female (18-30 y) } \\
1 \text { child }(2-4 \text { y) } \\
1 \text { child (5-7 y) }\end{array}$ & 475.87 & 416.48 & 390.35 & 415.71 & 374.33 & 316.11 & 309.00 & 308.22 \\
\hline $\begin{array}{l}\text { Family of } 4^{c} \\
\text { Male (31-50 y) } \\
\text { Female (30-50 y) } \\
1 \text { child }(8-11 \text { y) } \\
1 \text { child }(12-17 \mathrm{y})\end{array}$ & 626.95 & 621.00 & 586.7 & 617.27 & 562.96 & 497.07 & 491.12 & 487.39 \\
\hline
\end{tabular}

${ }^{a}$ Numbers in parentheses indicate that monthly Supplemental Nutrition Assistance Program (SNAP) allowance exceeds monthly cost; ${ }^{b}$ Monthly costs for women and men (aged 18-50 years) were estimated as the average costs for men and women in the age group 18-30 and 31-50 years; ' Monthly cost for women and men aged 18-50 and $\geq 51$ years and families of 4 include the cost of labor for food preparation, which account for $60 \%$ of total costs based on estimates by Davis and You. ${ }^{30}$ The MyPlate cost of food including labor was estimated as the monthly cost/0.60 for each age and gender category across scenarios. Additional cost was estimated as the MyPlate cost of food including labor minus (SNAP benefits + BRR), where BRR $=20 \% \times$ average monthly gross income of SNAP recipients. According to the US Department of Agriculture (2015), the average gross income for all SNAP households was $\$ 786 / \mathrm{mo}$, and the monthly SNAP benefits were $\$ 465$ for a family of 4, $\$ 127$ for female adults, and $\$ 126$ for male adults

Note: Data are from the US Department of Agriculture ${ }^{29}$ and Davis and You. ${ }^{30}$

to prepare meals, the research found that the current levels of SNAP benefits plus expected personal expenditures were not enough to cover the full cost of supporting a diet recommended by MyPlate. This analysis showed that after accounting for BRR, approximately $43 \%$ to $60 \%$ of the total monthly food cost including labor cost was covered by SNAP benefits. The analysis revealed that for a family of 4 with 2 parents (aged 3150 years) and 2 older children (1 aged 8-11 years and the other 1217 years), the monthly cost of food including the cost of labor ranged from a high of $\$ 1,249$ (when consuming only fresh fruits and vegetables) to a low of $\$ 1,109$ for a vegetarian diet consuming one-third fresh, frozen, and canned fruits and vegetables.

These estimates were higher than the 2016 USDA's low-cost food plan of $\$ 588 / \mathrm{mo}$ for a family of 4 (\$147.60/wk for a family consisting of 2 adults aged $20-50$ years and 2 children aged $2-3$ years and $4-5$ years). ${ }^{19}$ In addition, the current estimates were slightly lower than the USDA's liberal food plan of $\$ 1,276 /$ mo for a family of 4 (\$294.50/wk for a family consisting of 2 adults aged $20-50$ years and 2 children aged 6-8 years and 911 years). ${ }^{19}$ Several reasons for the differences in monthly cost could be that the USDA's food plans include other foods such as gravies and sauces, coffee and tea, soft drinks, sugars and candies, and soup. In addition, the model used to calculate the various food prices plans was based on the latest food consumption trends and food prices. The estimation in this report did not include current food 
consumption trends. Finally, the current analysis includes the cost of labor in food preparation.

Compared with the USDA's estimated cost of consuming MyPlate levels of fruits and vegetables (fresh, canned, frozen, dried, and $100 \%$ juice) of $\$ 2.10$ to $\$ 2.60$ per day, the fresh fruit and vegetable estimates (scenario 1) ranged from a low of $\$ 1.70$ for children aged 2-3 years to a high of $\$ 4.28$ for men aged $19-50$ years. ${ }^{22}$ Scenario 3 (which accounts for one-third fresh, frozen, and canned fruits and vegetables) more closely resembles the USDA's fruit and vegetable cost estimates, with a low of $\$ 1.68$ for children aged 2-3 years to a high of $\$ 4.22$ for men aged 19-50 years. In addition, the USDA found that a family of 4 (with 2 parents aged 40 years and 2 children, one aged 8 years and the other aged 10 years) would need to spend $\$ 61.80 /$ wk on fruits and vegetables using the thrifty food plan to satisfy MyPlate dietary guidelines. ${ }^{22}$ This is considerably less than the current estimate of $\$ 90.02$ for a family of 4 with 2 children of the same age using scenario 3. Several reasons for the cost difference might be that the USDA's cost estimates were from 2013 retail prices. Also, that model included prices for fresh, frozen, canned, dried, and juiced products. ${ }^{22}$

This study had several limitations. First, because the USDA's age categories for MyPlate dietary recommendations were different from the SNAP recipient age categories, the age categories in this study's model had to be adjusted. Because of this, the monthly cost projections could be slightly skewed. Second, 6 food cost scenarios were created that took into account sourcing fruits and vegetables from $100 \%$ fresh produce and a mix of fresh, frozen, and canned produce, as well as the cost of vegetarian diets. The authors recognized that individuals and families do not follow these simulated scenarios precisely. Therefore, this study's estimates from the 6 scenarios could vary from the true monthly costs that individuals spend on food.

This study calculated the cost of following MyPlate's dietary recommendations for all food groups (fruits, vegetables, grains, dairy, and protein), including the cost of consuming fresh, frozen, and canned produce. The true costs, including food prices and labor, of adhering to the federal dietary guidelines were calculated. Results from this analysis indicated that low-income families need to incur additional costs for healthy food consumption as recommended by the federal dietary guidelines.

\section{IMPLICATIONS FOR RESEARCH AND PRACTICE}

Since the 1970s, the US has experienced an increase in largely preventable chronic diseases, including obesity, type 2 diabetes, and heart disease, that are associated with poor diets. It is estimated that the direct medical costs of heart disease in the US account for nearly $\$ 270$ billion annually. ${ }^{34}$ Research showed that increased consumption of fruits and vegetables according to MyPlate guidelines could prevent over 127,000 deaths annually from heart disease, and the value of this increased longevity would exceed $\$ 11$ trillion. ${ }^{35}$

The Supplemental Nutrition Assistance Program is the largest federal food assistance program and is effective at reducing food insecurity while also improving child and adult health outcomes. ${ }^{9}$ Unfortunately, many families receiving SNAP still report significant financial barriers to purchasing healthy food with their benefits. ${ }^{14,15}$ Current federal proposed budget cuts to SNAP program decrease the amount of benefits available for food purchases and fewer people would have access to the program. ${ }^{18}$ An analysis using the most current data is needed to inform policy makers regarding the true costs of healthy eating so that they have up-to-date research when making policy decisions. Data related to the cost of consuming a healthy diet are imperative to informing policy makers.

\section{ACKNOWLEDGMENTS}

Dr Kranti Mulik's time was supported by the Union of Concerned Scientists and Dr Lindsey Haynes-Maslow's time was supported by North Carolina State University.

\section{REFERENCES}

1. Trust for America's Health. $F$ as in fat: obesity 2013 report. http://healthya mericans.org/report/108/. Accessed December 3, 2016.

2. Flegal KM, Carroll MD, Kit BK, Ogden CL. Prevalence of obesity and trends in the distribution of body mass index among US adults, 1999-2010. JAMA. 2012;307:491-497.

3. Centers for Disease Control and Prevention. Chronic diseases: the power to prevent, the call to control: at a glance 2009. https://www.cdc.gov/chronicdisease/pdf/ 2009-power-of-prevention.pdf. Accessed September 17, 2016.

4. Lin B. Diet Quality Usually Varies by Income Status. Washington, DC: US Dept of Agriculture, Economic Research Service; 2005. Report No. 3.

5. Haynes-Maslow L, Parsons SE, Wheeler SB, Leone LA. Understanding barriers to fruit and vegetable consumption among low-income individuals: a qualitative study. Prev Chron Dis. 2013;10:1202-1206.

6. Kirkpatrick S. Understanding and addressing barriers to healthy eating among low-income Americans. J Acad Nutr Diet. 2012;112:617-620.

7. Leung C, Musicus A, Willett W, Rimm E. Improving the nutritional impact of the Supplemental Nutrition Assistance Program: perspectives from the participants. Am J Prev Med. 2017; 52:S193-S198.

8. USDA. Supplemental Nutrition Assistance Program. http://www.fns.usda.gov/ snap/supplemental-nutrition-assistanceprogram-snap. Accessed October 2, 2016.

9. Center on Budget and Policy Priorities Policy Basics: introduction to the Supplemental Nutrition Assistance Program (SNAP). http://www.cbpp.org/ research/policy-basics-introduction-to-thesupplemental-nutrition-assistance-prog ram-snap?fa $=$ view\&id $=2226$. Accessed October 3, 2016.

10. Mabli J, Worthington J. Supplemental Nutrition Assistance Program participation and child food security. Pediatrics. 2014;133:1-10.

11. Ratcliffe C, McKernan S, Zhang S. How much does the Supplemental Nutrition Assistance Program reduce food insecurity? Am J Agric Econ. 2011;93:1082-1098.

12. Nord M. How much does the Supplemental Nutrition Assistance Program alleviate food insecurity? Evidence 
from recent programme leavers. Public Health Nutr. 2012;15:811-817.

13. Gregory CA, Deb P. Does SNAP improve your health? Food Policy. 2015;50:11-19.

14. Haynes-Maslow L, Auvergn LA, Mark BA, Ammerman A, Weiner BJ. Low-income individuals' perceptions about fruit and vegetable access programs: a qualitative study. J Nutr Educ Behav. 2015;47:317-324.

15. Mushi-Brunt C, Haire-Joshu D, Elliot M. Food spending behaviors and perceptions are associated with fruit and vegetable intake among parents and their preadolescent children. J Nutr Educ Behav. 2007:39:26-30.

16. Fox MK, Hamilton W, Lin B. Effects of Food Assistance and Nutrition Programs on Nutrition and Health. Washington, DC: Food and Nutrition Research Service, USDA; 2004.

17. Gregory CA, Ver Ploeg M, Andrews M, Coleman-Jensen A. Supplemental Assistance Program (SNAP) Participation Leads to Modest Changes in Diet Quality. Economic Research Report 147. Washington, DC: US Dept of Agriculture, Economic Research Service.

18. Center on Budget and Policy Priorities. House 2017 budget plan would slash SNAP by more than 150 billon over ten tears. http://www.cbpp.org/rese arch/food-assistance/house-2017-budgetplan-would-slash-snap-by-more-than-150billion-over-ten. Accessed September 15, 2016.

19. USDA. Official USDA food plans: cost of food at home at four levels, U.S. average, July 2016. http://www.cnpp. usda.gov/sites/default/files/CostofFood Jul2016.pdf. Accessed September 26, 2014.
20. Lin BH, Wendt M, Guthrie JF. Impact on energy, sodium and dietary fibre intakes of vegetables prepared at home and away from home in the USA. Public Health Nutr. 2013;16:1937-1943.

21. Britten P, Cleveland LE, Koegel KL, Kuczynski KJ, Nickols-Richardson SM. Updated US Department of Agriculture Food Patterns meet goals of the 2010 dietary guidelines. J Acad Nutr Diet. 2012; 112:1648-1655.

22. USDA. The Cost of Satisfying Fruit and Vegetable Recommendations in the Dietary Guidelines. Economic Research Service. https://www.ers.usda.gov/webdocs/ publications/42902/56772_eb27.pdf?v= 42426. Accessed January 2, 2017.

23. USDA. Retail prices for beef, pork, poultry cuts, eggs and dairy products. https://www.ers.usda.gov/webdocs/Da taFiles/Meat_Price_Spreads_17995/cuts. $x l s ? v=42809$. Accessed August 1, 2016.

24. USDA. Quarterly-Food-at-HomePrice-Database 2 (QFAHPD- 2). http:// www.ers.usda.gov/data-products/quarte rly-food-at-home-price-database.aspx. Accessed August 1, 2016.

25. USDA. Fruit and vegetable prices. http://www.ers.usda.gov/data-products/ fruit-and-vegetable-prices.aspx. Accessed August 1, 2016.

26. USDA. Food and Nutrition Service. 2016 Supplemental Nutrition Assistance Program (SNAP) Eligibility. http://www.fns.usda.gov/snap/eligibility \#Income. Accessed August 3, 2016.

27. Office for Human Research Protections. Human Subject Regulations Decision Charts. https://www.hhs.gov/ ohrp/regulations-and-policy/decisioncharts/index.html\#c1. Accessed August 3, 2016.
28. USDA. MyPlate Dietary Guidelines. https://www.choosemyplate.gov/dieta ry-guidelines. Accessed November 17, 2016.

29. USDA, Food and Nutrition Services. Department of Agriculture. Characteristics of Supplemental Nutrition Assistance program households: fiscal year 2015. https://fns-prod.azureedge.net/ sites/default/files/ops/Characteristics2015. pdf. Accessed August 15, 2016.

30. Davis GC, You W. The Thrifty Food Plan is not thrifty when labor cost is considered. J Nutr. 2010;140:854-857.

31. Ziliak JP. Effective tax rates and guarantees in the Food Stamp Program. University of Kentucky. http://gattonweb. uky.edu/Faculty/ziliak/ERS_FSP_Rates\& Guarantees_042308.pdf. Accessed February 1, $201 \overline{7}$.

32. Rickman JC, Bruhn CM, Barrett DM. Nutritional comparison of fresh, frozen, and canned fruits and vegetables II. Vitamin A and carotenoids, vitamin E, minerals and fiber. I Sci Food Agric. 2007;87:1185-1196.

33. Kader AA. Flavor quality of fruits and vegetables. I Sci Food Agric. 2008;88: 1863-1868.

34. Heidenreich PA, Trogdon JG, Khavjou OA, et al. Forecasting the future of cardiovascular disease in the United States: a policy statement from the American Heart Association. Circulation. 2011;123:933-944.

35. Union of Concerned Scientists. The $\$ 11$ Trillion Dollar Reward: How Simple Dietary Changes Can Save Lives and Money, and How We Get There. Washington, DC; 2013. http://www.ucsusa. org/sites/default/files/legacy/assets/docu ments/food_and_agriculture/11-trillionreward.pdf. Accessed September 3, 2016. 


\section{CONFLICT OF INTEREST}

The authors have not stated any conflicts of interest. 